\title{
From Twitter to Megaphones: Seven Lessons Learned about Public Health Crisis Communication
}

\author{
Lisa Gualtieri, $\mathbf{P h D}^{1}$ \\ ${ }^{1}$ Tufts University School of Medicine
}

In Boston we took the availability and quality of our tap water for granted until May 1, 2010, when a major water pipe break interrupted water service to two million Greater Boston residents. Information spread quickly to citizens about the problem and what to do, all the more notable because the water main break occurred on a Saturday. In this age of consumer paranoia about withheld information, the Massachusetts Water Resources Authority (MWRA) was in front of cameras and online, communicating what they knew and what they were doing. Tufts University and the Boston Public Health Commission used communication channels ranging from Twitter to megaphones to get the word out. Their behind-the-scenes emergency planning processes, their response to this incident, and seven lessons learned from this short-lived crisis are applicable to many other crises.

\section{The Evolution of the Tufts Emergency Alert System:}

Because I learned about the broken water main in a text message from Tufts University, where I teach, I spoke to Geoff Bartlett, Technical Services Manager in the Department of Public and Environmental Safety (DPES) at Tufts about the process they used to communicate about the broken water main. First he told me how Tufts Emergency Alert System started and evolved. Following the Virginia Tech massacre in 2007, DPES, University Relations, and University Information Technology invested in emergency notification system technology and developed policies for when and how it would be used. The Tufts Emergency Alert System was initially intended for life threatening emergencies after the events on the Virginia Tech campus showed the need for rapid and reliable campus-wide communication. In requesting student and employee contact information, Tufts made this clear since they thought people would be reluctant to participate if they anticipated inconsequential messages.

Tufts first used the emergency alert system to inform the campus of the status of a power outage in October 2008 because the email communication plan in place for this type of Tier 2 emergency wouldn't work because of the lack of electricity. This initial use led to the revised policy that the emergency alert system should be used aggressively for dire emergencies but less aggressively when there is no threat to health, safety, or life. Almost exactly one year later, there was another power outage in October 2009, and short text messages were sent. While there was planning for H1N1, the emergency alert system was never used because there was no urgency to push messages. The third use was for the water main break. 


\section{How Tufts Creates Messages:}

While Tufts considered preparing messages in advance, it didn't seem possible to anticipate every situation. Instead they created "Strunk and White" guidelines for crisis communication. Their three guiding principles for creating initial messages are:

1. What is happening

2. What you need to do now

3. Where to go for more information.

Messages must be succinct because of cell phone screen size and to increase the likelihood people read them, avoid jargon and abbreviations, and be composed for easy conversion into speech. While the Tufts community is tech-savvy, they are aware that not everyone is connected all the time therefore some messaging includes spreading the word. For many emergencies, especially life-threatening ones like violent criminal incident or tornado warning, content is prescripted by Tufts using sources such as the Massachusetts Department of Public Health.

In the case of the water main break, Massachusetts Emergency Management Agency sent out the initial message. When Geoff received the message on Saturday, May 1, he was in a command post on campus with police, fire, and EMS personnel where they were managing the public safety aspects of the Spring Fling concert. Because there was no reported danger or health threat, email was used initially. Later in the day, after Massachusetts Governor Deval Patrick declared a state of emergency, DPES fully activated the emergency alert system. In addition, email, word of mouth, Twitter, and the web were used to spread information.

I asked Geoff if there was concern about any health issues arising from students who drank tap water. He said that there was an FAQ that included the consequences of ingesting water. However the information they were receiving from the state agencies, and therefore their focus, was on the status of the water main break and what to do, such as the boil water order. Student feedback after the crisis ended was largely positive but included that there were terms, like boil water order, that they didn't understand.

\section{The Boston Public Health Commission Emergency Preparedness Process:}

To see how a public health organization responded, I looked at the Boston Public Health Commission (BPHC) website and spoke to Susan Harrington. She had guest-lectured in my Online Consumer Health course about their use of the web and social media and I wanted to see how they deployed them in an emergency like the water main break.

BPHC and its partners participate in emergency preparedness exercises to refine their coordination and response. In 2007, BPHC worked with the postal office on a large-scale exercise and last year they responded to the real-life H1N1 epidemic. Just last month, BPHC invited businesses, health care settings, and other partner organization to a Flu Review, where they discussed how BPHC responded, including what they did well, what didn't work, and made recommendations as they prepare for the next flu season this fall. 


\section{How the Boston Public Health Commission Alerted Residents:}

Susan was in a city not affected by the burst water main on the Saturday the news was announced and received a call from work alerting her to the situation. Working in concert with federal, state, and city agencies, the Mayor's Office and BPHC relayed important information and coordinated response efforts. The immediate issue was reaching people, which the BPHC first did through Twitter, Facebook, and their website. The Mayor's Office posted information on its own sites and used its reverse 911 phone system to alert residents. Boston police officers drove up and down streets using megaphones and loudspeakers. BPHC set up conference calls with area hospitals and staffers were sent out to food-service establishments who needed to quickly adapt their procedures for the boil water order. Throughout the weekend, the Mayor's 24-hour hotline added staffers to help answer any questions residents had. The Mayor's Office and BPHC also called upon their partners, which included faith-based organizations, schools, and businesses, to spread the message through their own channels, and asked residents to inform the elderly who may not have access to the web and social media. The challenge was responding quickly and reaching as many people, wired or not, as possible. These techniques had been used to spread the word about H1N1 vaccine availability.

Twitter proved very effective at relaying up-to-the-minute news. While Twitter is global, people use the \#Boston hashtag and other filters to get local information including traffic updates, event listings, and even local celebrity sightings. Not long after boil water order was issued, the Twitterverse was abuzz with the news - even dubbing a new hashtag for the emergency: \#aquapocolypse. The most influential - and most followed - Twitter profiles were not only pushing out timely information, but passing on questions to BPHC, allowing them to respond and dispel any myths.

\section{Creating Fact Sheets:}

No matter what the crisis, some people worry and they are the ones who especially need facts. One of the main BPHC priorities was posting information and fact sheets to the BPHC website. As a homeowner Susan knew what questions she had, but she had to consider the broad demographics of Boston in terms of where people live, the languages they speak, and their access to water.

BPHC worked with the Massachusetts Department of Public Health to create easy-to-read and culturally appropriate guidelines for the boil water order for Bostonians, including translating the fact sheets into multiple languages using a professional translation company with proofing by Commission staffers. These materials were later updated to reflect the lifting of the boil water order and subsequent flushing out instructions.

I asked Susan about the extent to which they date materials. In a crisis, knowing that an update is available and when it was issued is crucial. Throughout the flu response and boil water order, they posted dates on their websites, but in a non-emergency she said it is a challenge to keep an entire website updated. Fact sheets often are dated but other online materials may not be. 


\section{Health Issues and Disease Tracking:}

I taught a course in Shanghai once and remembered the advice I was given about the level of bacteria being higher in the tap water than Americans are used to. I slipped back into Shanghaimode and remembered to rinse my toothbrush with bottled water and the myriad of other pointers I had been given. I was curious if Boston residents who drank tap water during the emergency expressed health concerns. Susan said that if pathogens were in the water, people may have experienced minor gastrointestinal illness after consuming that water. A greater concern would be for residents who are immunocompromised.

The BPHC uses a sophisticated surveillance system to track diseases in Boston. (In fact, Boston has been nationally recognized for its disease tracking system.) Health care settings report diseases to BPHC, which in turn, conducts a follow-up investigation and identifies the source of the illness, such as food contamination. These disease patterns are tracked over time. In the case of the boil water order, there was no spike in gastrointestinal illnesses. Google has a less formal process of tracking disease patterns, collecting search phrases to find trends including the spread of illness. Google's H1N1 flu trend matched up fairly well to Massachusetts' trend lines.

\section{Lessons Learned:}

Susan Harrington and Geoff Bartlett both thought the MWRA did a great job of letting people know what they knew, what they didn't know, and what they were doing to find answers and repair the pipe. This was essential not just to inform people but to allay paranoia and fears given well-publicized situations like Toyota and Vioxx where information was not publicly disclosed in a timely fashion.

Some lessons learned about rapid health communication from the water main break are:

1. Develop a rubric to assess the type of crisis as it impacts your institution. When the crisis is over, review, solicit feedback, and refine using what the military call an After Action Review.

2. Identify and coordinate with partners in advance. In the case of the water main break, an impressive number of groups coordinated efforts seemingly seamlessly and, in many cases, behind the scenes.

3. Prepare a communication plan for each type of crisis. While newspapers write obituaries for famous people in advance, you can't anticipate all eventualities. However, you can prepare guidelines and immediately use them. Flexibility needs to be built in to communication plans, even to the definition of a life threatening emergency and when to select modalities that "wake you up" or more passive ones like email.

4. Carefully construct messages to convey needed information succinctly. High-quality materials take time to produce because it's important to first gather facts and then create and review accurate, appropriate, and easy-to-understand information, be they short like text and Twitter messages, or less constrained by length. Dating material is especially important in a crisis.

5. Create messages that inform and allay unnecessary fears. Think like - or talk to your target audience. Be careful about jargon, although everyone in Greater Boston quickly became conversant quickly with "MWRA" and "boil water order", which are not 
in the common vernacular. Terminology was also an issue with H1N1: swine flu was the term adopted by the press initially, but it was distracting because of the association with pigs.

6. Use social media, which can be both fast and local. Use emerging informal partners, who Malcolm Gladwell calls mavens, to facilitate the spread of messages in Twitter. But even when people are wired, they aren't always online. The low tech megaphone and word of mouth works best for some.

7. Use crises to educate people. While the water main break left many people with a heightened appreciation for their tap water, it was short-lived. However there may be a missed opportunity here to educate people about water sources, safety, and conservation as well as about emergency response.

\section{Correspondence:}

Lisa Gualtieri, $\mathrm{PhD}$

Tufts University School of Medicine

136 Harrison Avenue

Boston, MA 02111

l.gualtieri@tufts.edu 